\title{
Model Pembelajaran Direct Instruction Dengan Metode Study Kasus Untuk Meningkatkan Prestasi Belajar Matematika Siswa
}

\author{
Gusti Ayu Warniti ${ }^{1}$ \\ 1SMP Negeri 2 Blahbatuh, \\ Gianyar, Indonesia \\ email:warniti578@gmail.com
}

\begin{abstract}
Abstrak
Penelitian ini merupakan penelitian tindakan kelas yang bertujuan untuk meningkatkan prestasi belajar Matematika siswa kelas VIII D SMP Negeri 2 Blahbatuh pada semester I tahun pelajaran 2019/2020 melalui penggunaan model pembelajaran Direct Instruction dengan metode study kasus dalam proses pembelajaran. Data dalam penelitian ini dikumpulkan dengan tes prestasi belajar. Metode analisis datanya adalah deskriptif. Hasil yang diperoleh dari penelitian ini penggambaran secara lengkap dapat dijabarkan sebagai berikut: hasil yang diperoleh pada awalnya 68,42 dengan ketuntasn belajar hanya mencapai $31,57 \%$, pada siklus I meningkat menjadi 73,55 dengan ketuntasan belajar mencapai $73,68 \%$ dan pada siklus II meningkat menjadi 80,52 dengan ketuntasan belajar mencapai $92,10 \%$. Hasil tersebut setelah dilakukan analisis menggunakan analisis deskriptif diperoleh kesimpulan bahwa prestasi belajar Matematika siswa kelas VIII D SMP Negeri 2 Blahbatuh pada semester I tahun pelajaran 2019/2020 dapat ditingkatkan melalui penerapan model pembelajaran Direct Instruction dengan metode study kasus.
\end{abstract}

Kata Kunci: Model Pembelajaran Direct Instruction, Metode Study Kasus, Prestasi Belajar

\begin{abstract}
This research is a classroom action research that aims to improve the mathematics learning achievement of class VIII D students of SMP Negeri 2 Blahbatuh in the first semester of the 2019/2020 academic year through the use of the Direct Instruction learning model with the case study method in the learning process. The data in this study were collected by means of learning achievement tests. The data analysis method is descriptive. The results obtained from this study can be described in full as follows: the results obtained initially were 68.42 with learning completeness only reaching $31.57 \%$, in cycle I increased to 73.55 with learning completeness reaching $73.68 \%$ and at cycle II increased to 80.52 with learning completeness reaching $92.10 \%$. After analyzing these results using descriptive analysis, it was concluded that the mathematics learning achievement of class VIII D students of SMP Negeri 2 Blahbatuh in the first semester of the 2019/2020 academic year could be improved through the application of the Direct Instruction learning model with the case study method.
\end{abstract}

Keywords: Direct Instruction Learning Model, Case Study Method, Learning Achievement.

\section{Pendahuluan}

Lampiran Permendiknas RI No. 22 (2006, 416) juga menyebutkan bahwa, untuk meningkatkan keefektifan pembelajaran, sekolah diharapkan menggunakan teknologi informasi dan komunikasi seperti komputer, alat peraga, atau media lainnya. Sementara itu, dalam Permendiknas RI No. 41 (2007: 6) disebutkan bahwa proses pembelajaran pada setiap satuan pendidikan dasar dan menengah harus interaktif, inspiratif, menyenangkan, menantang, dan memotivasi siswa untuk berpartisipasi aktif serta memberikan ruang yang

\footnotetext{
${ }^{*}$ Corresponding author.
}

Received 03 Februari 2020; Accepted 31 July 2020; Available online 1 September 2020

(C) 2020 MPI. All Rights Reserved 
cukup bagi prakarsa, kreativitas dan kemandirian sesuai dengan bakat, minat, dan perkembangan fisik serta psikologis siswa.

Keterampilan dan kecermatan guru dalam memilih metode untuk setiap pembelajaran sangat penting karena mempengaruhi kelancaran proses pembelajran, hasil belajar dan keaktifan anak (Amri, 2013). Yang tidak kalah pentingnya adalah pemahaman guru tentang proses pembelajaran dapat berlangsung aktif, kreatif, dan menarik jika dalam diri siswa tumbuh rasa ingin tahu, mencari jawaban atas pertanyaan, memperluas dan memperdalam pemahaman dengan menggunakan metode yang efektif. Rasa ingin tahu siswa muncul dan terlihat ketika sudah mulai mengajukan pertanyaan-pertanyaan. Pertanyaan inilah nantinya yang akan menjadi bahan pembelajaran untuk dicari jawabannya bersama-sama antara guru dan siswa. Agar mampu menjawab semua pertanyaan yang dilontarkan siswa dan memberikan dampak yang baik terhadap kelangsungan pembelajaran mereka, seorang guru harus benar-benar memiliki pengetahuan yang mendalam tentang materi yang diajarkan sehingga dia layak disebut seorang guru yang kompeten (Dahar, 1989).

Suatu pembelajaran akan bermakna ketika para siswa ikut berperan aktif dalam kegiatan di kelas. Peran serta keaktifannya tersebut akan menumbuhkan berbagai hal yang positif bagi dirinya (Dimyati, 2001). Seperti kepercayaan diri, sikap sosial dan tanggung jawab. Untuk mewujudkan hal tersebut tentunya peran guru teramat sangat diperlukan, terutama ketika memutuskan model pembelajaran seperti apa yang sekiranya tepat untuk diterapkan di dalam kelas (Djamarah, 2002).

Berdasarkan hasil pengamatan dan pengalaman bahwa kegiatan belajar mengajar pendidikan Matematika pada umumnya selalu menjadi kurang menarik bagi siswa karena dianggap sebagai pelajaran yang membosankan yang memerlukan latihan-latihan banyak yang monoton, sehingga membuat murid jauh semakin jenuh.

Sehubungan dengan proses pembelajaran yang berlangsung di SMP Negeri 2 Blahbatuh dari hasil pengumpulan data awal didapat nilai rata-rata siswa kelas VIII D pada mata pelajaran Matematika hanya mencapai 68,42 dengan ketuntasan belajar hanya mencapai $31,57 \%$. Hasil tersebut tentu tidak sesuai dengan harapan keberhasilan pendidikan yang ditetapkan yaitu 73,00 . Tentang pelajaran yang disampaikan, jika pelajaran sempat diterima peserta didik dan belum berhasil, boleh jadi penyebabnya dikarenakan keterbatasan kemauan guru dalam menerapkan semua keilmuan yang dikuasai demi pencapaian hasil maksimal dalam pembelajaran

Selanjutnya peneliti/guru melaksanakan perbaikan pembelajaran dengan menerapkan model pembelajaran Direct Instruction (pengajaran langsung) dengan metode study kasus supaya dapat meningkatkan prestasi belajar Matematika siswa khususnya siswa kelas VIII D di SMP Negeri 2 Blahbatuh pada semester I tahun pelajaran 2019/2020.

Model pembelajaran Direct Instruction (pengajaran langsung) dengan metode study kasus adalah strategi mengajar yang mengkombinasikan rasa ingin tahu siswa (Charuer et al., 2005). Penggunaan strategi ini untuk meningkatkan pengembangan keterampilan berpikir kritis melalui kegiatan belajar. Penerapan strategi pembelajaran Direct Instruction (pengajaran langsung) dengan metode study kasus ini merupakan upaya untuk membangkitkan rasa ingin tahu siswa. Dorongan itu berkembang melalui proses merumuskan pertanyaan, merumuskan masalah, mengamati, dan menerapkan informasi baru dalam meningkatkan pemahaman mengenai sesuatu masalah. Rasa ingin tahu itu terus ditumbuhkan untuk meningkatkan semangat bereksplorasi sehingga siswa belajar secara aktif.

\section{Metode Penelitian}

Penelitian ini dilakukan di SMP Negeri 2 Blahbatuh. Lingkungan sekolah ini sangat nyaman karena hubungan dengan masyarakat sekitar sekolah sangat baik, hubungan antara sekolah dengan masyarakat sekitar juga sangat harmonis, sehingga menimbulkan rasa mutualisme antara sekolah dan masyarakat sekitar.

Penelitian ini merupakan penelitin tindakan kelas yang akan dilaksanakan dalam dua siklus. Jika pada siklus pertama prestasi belajar Matematika siswa belum memenuhi kriteria keberhasilan, maka berdasarkan hasil refleksi akan dilakukan perbaikan pada siklus 
seanjutnya. Secara operasional prosedur dasar pengembangan tindakan yang akan dilakukan dapat dijabarkan sebagai berikut:

Untuk penelitian ini penulis memilih rancangan penelitian tindakan yang disampaikan oleh Model (Arikunto, 2007) dengan melalui pentahapan, yaitu: Perencanaan, Pelaksanaan, Observasi dan Refleksi, seperti terlihat pada gambar berikut.

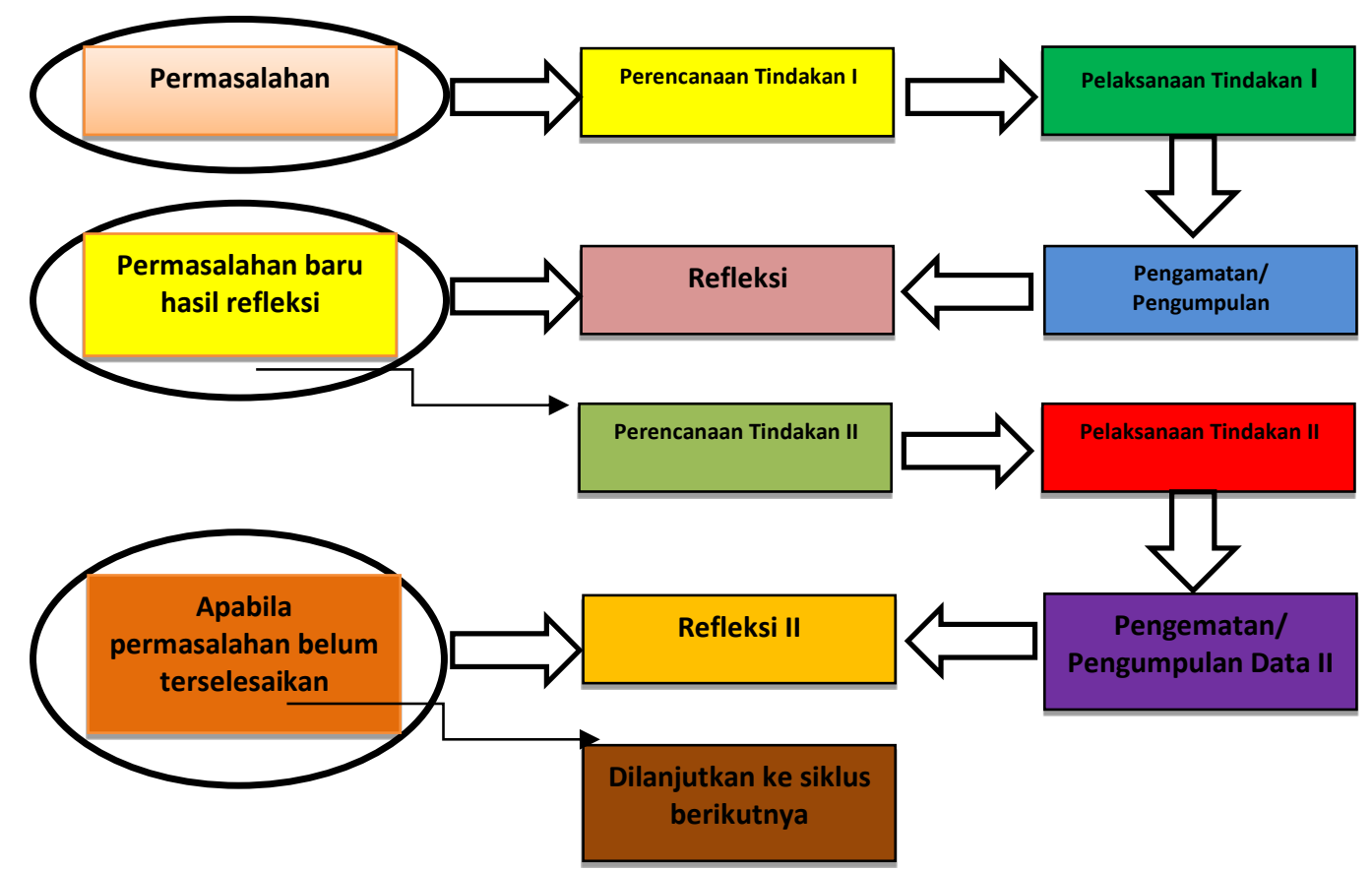

Gambar: 01 Alur Penelitian Tindakan kelas Model (Arikunto, 2007)

Prosedur:

\section{Perencanaan} instrumen.

Pada tahap ini peneliti membuat RPP, berkonsultasi dengan teman sejawat membuat

Pada tahap menyusun rancangan diupayakan ada kesepakatan antara guru dan sejawat. Rancangan dilakukan bersama antara peneliti yang akan melakukan tindakan dengan guru lain yang akan mengamati proses jalannya tindakan. Hal tersebut untuk mengurangi unsur subjektivitas pengamat serta mutu kecermatan pengamatan yang dilakukan.

\section{Pelaksanaan Tindakan}

Tahap pelaksanaan tindakan dilakukan dengan pembelajaran di kelas. Pada tahap ini guru peneliti giat melakukan tindakan menggunakan Model pembelajaran Direct Instruction dengan metode study kasus. Rancangan tindakan tersebut sebelumnya telah dilatih untuk dapat diterapkan di dalam kelas sesuai dengan skenarionya. Skenario dari tindakan diupayakan dilakspelajaran dengan baik dan wajar.

\section{Pengamatan atau observasi}

Tahap ini sebenarnya berjalan bersamaan dengan saat pelaksanaan. Pengamatan dilakukan pada waktu tindakan sedang berjalan, jadi, keduanya berlangsung dalam waktu yang sama.

Pada tahap ini, guru yang bertindak sebagai peneliti melakukan pengamatan dan mencatat semua hal yang diperlukan dan terjadi selama pelaksanaan tindakan berlangsung. Pengumpulan data ini dilakukan dengan menggunakan tes prestasi belajar yang telah 
tersusun, termasuk juga pengmatan secara cermat pelaksanaan skenario tindakan dari waktu ke waktu serta dampaknya terhadap proses dan prestasi belajar anak.

\section{Refleksi}

Tahapan ini dimaksudkan untuk mengkaji secara menyeluruh tindakan yang telah dilakukan, berdasarkan data yang telah terkumpul, kemudian dilakukan evaluasi guna menyempurnakan tindakan berikutnya.

Refleksi dalam PTK mencakup analisis, sintesis, dan penilaian terhadap hasil pengamatan atas tindakan yang dilakukan. Jika terdapat masalah dari proses refleksi maka dilakukan proses pengkajian ulang melalui siklus berikutnya yang meliputi kegiatan: perencanaan ulang, tindakan ulang, dan pengamatan ulang shingga permasalahan dapat teratasi.

Metode yang digunakan untuk menganalisis data hasil penelitian ini adalah metode deskriptif. Untuk data kuantitatif dianalisis dengan mencari mean, median, modus, membuat interval kelas dan melakukan penyajian dalam bentuk tabel dan grafik. Indikator keberhasilan penelitian yang diusulkan dalam penelitian ini pada siklus I dan siklus II mencapai nilai ratarata 74,00 dengan ketuntasan belajar minimal $85 \%$.

\section{Hasil Dan Pembahasan}

Data awal yang diperoleh dengan rata-rata 68,42 dengan ketuntasan belajar hanya mencapai 31,57\% menunjukkan bahwa kemampuan siswa dalam mata pelajaran Matematika masih sangat rendah mengingat kriteria ketuntasan belajar siswa untuk mata pelajaran ini di SMP Negeri 2 Blahbatuh adalah 73,00. Dengan nilai yang sangat rendah seperti itu maka peneliti mengupayakan untuk dapat meningkatkan prestasi belajar siswa menggunakan model pembelajaran Direct Instruction dengan metode study kasus. Akhirnya dengan penerapan metode/model pembelajaran Direct Instruction dengan metode study kasus yang benar sesuai teori yang ada, peningkatan rata-rata prestasi belajar anak/siswa pada siklus I dapat diupayakan dan mencapai rata-rata 73,55. Namun rata-rata tersebut belum maksimal karena hanya 28 siswa memperoleh nilai di atas KKM sedangkan 10 yang lainnya belum mencapai KKM. Sedangkan prosentase ketuntasan belajar mereka baru mencapai 73,68\%.

Pelaksanaan pada siklus II sudah berjalan lebih baik daripada siklus I. Siswa terlihat lebih aktif dan bersemangat dalam belajar. Hal ini dikarenakan kasus-kasus yang yang digunakan guru dalam pembelajaran merupakan kasus yang terkini dan populer di kalangan siswa. Sehingga rasa ingin tahu siswa menjadi tumbuh dalam proses pembelajaran. Hal ini berdampak positif terhadap peningkatan prestasi belajar siswa pada siklus II menjadi rata-rata 80,52 dengan presentase ketuntasan mencapai $92,10 \%$, hal ini menunjukkan terjadinya peningkatan yang sangat signifikan.

Hasil penelitian ini diperkuat oleh penelitian yang dilakukan oleh (Murjani, 2019) dengan judul Penerapan Model Pembelajaran Direct Instruction dengan Media Gambar untuk Meningkatkan Prestasi Belajar IPS. Hasil yang diperoleh dari penelitian ini adalah penerapan model pembelajaran Direct Instructiondengan media gambardapat meningkatkan prestasi belajar IPS siswakelas IX H. Ini terbukti dari hasil yang diperoleh pada awalnya dengan nilai rata-rata 67,50 , pada siklus I menjadi 75,00 dan pada siklus II meningkat menjadi 80,88 Ketuntasan belajar meningkat dari $32,35 \%$ pada awal pembelajaran menjadi $73,52 \%$ pada siklus I dan $94,11 \%$ pada siklus II. Kesimpulan yang diperoleh dari penelitian ini adalah penerapan pembelajaran Direct Instruction dengan media gambar dapat meningkatkan prestasi belajar IPS siswa kelas IX H semester I SMP Negeri 2 Gianyar tahun pelajaran 2018/2019.

Selanjutnya penelitian yang dilakukan oleh (Pritandhari, 2017) dengan judul Implementasi Model Pembelajaran Direct Instruction Untuk Meningkatkan Kemampuan Berpikir Kreatif Mahasiswa. Dalam penelitiannya disimpulkan bahwa model pembelajaran Direct Instruction dapat meningkatkan kemampuan berpikir kreatif mahasiswa. Hal ini dikarenakan mahasiswa yang belajar menggunakan model pembelajaran Direct Instructiondapat belajar secara langsung sesuai dengan teori duia nyata. Dengan belajar 
secara langsung mahasiswa dapat mengaitkan teori yang sudah didapat dengan permasalahan yang ada di dunia nyata. Hal ini akan mendorong mahasiswa untuk berpikir lebih kreatif.

Model Pembelajaran Direct Instruction (model pengajaran langsung) dirancang khusus untuk menunjang proses belajar siswa yang berkaitan dengan pengetahuan prosedural dan pengetahuan deklaratif yang terstruktur dengan baik, yang dapat diajarkan dengan pola kegiatan yang bertahap, selangkah demi selangkah. Hal ini sesuai dengan pendapat Arends (2001), yang menyatakan bahwa "The Direct Instruction model was specifically designed to promote student learning of procedural knowledge and declarative knowledge that is well structured and can be taught in a stepby-step fashion".

Sedangkan (Carin, 1993) berpendapat bahwa Direct Instruction secara sistematis menuntun dan membantu siswa untuk melihat hasil belajar dari masing-masing tahap demi tahap. Sementara (Kardi, 2001) mendefinisikan "Model Pembelajaran Langsung (MPL) adalah suatu strategi pembelajaran yang digunakan untuk mengajarkan konsep dan keterampilan." Apabila guru menggunakan model pembelajaran langsung ini, guru mempunyai tanggung jawab untuk mengidentifikasikan tujuan pembelajaran dan tanggungjawab yang besar terhadap penstrukturan isi/materi atau keterampilan, menjelaskannya kepada siswa, pemodelan/mendemonstrasikan yang dikombinasikan dengan latihan, memberikan kesempatan kepada siswa untuk berlatih menerapkan konsep atau keterampilan yang telah dipelajari serta memberikan umpan balik (Adnyana, 2006).

\section{Simpulan}

Dari data awal ada 26 anak mendapat nilai di bawah KKM pada siklus I menurun menjadi 10 anak dan siklus II hanya 3 anak mendapat nilai di bawah 73,00 (KKM). Dari ratarata awal 68,42 naik menjadi 73,55 pada siklus I dan pada siklus II naik menjadi 80,52. Dari data awal anak yang tuntas hanya 12 orang sedangkan pada siklus I menjadi lebih banyak yaitu 28 anak dan pada siklus II sebanyak 35 siswa sudah mampu memenuhi KKM. Semua bukti tersebut dapat dicapai adalah akibat kesiapan dan kerja keras peneliti dari sejak pembuatan proposal, review, penyusunan kisi-kisi dan instrumen penelitian, penggunaan sarana trianggulasi data sampai pada pelaksanaan penelitian yang diakhiri dengan penulisan laporan ini. Data tersebut membuktikan bahwa penggunaan model pembelajaran Direct Instruction dengan metode study kasus dapat meningkatkan prestasi belajar Matematika siswa kelas VIII D pada semester I tahun pelajaran 2019/2020.

\section{Daftar Pustaka}

Amri, Sofan. 2013. Peningkatan Mutu Pendidikan Sekolah Dasar dan Menengah. Jakarta: PT. Prestasi Pustakaraya.

Arikunto, Suharsimi; Suhardjono; Supardi. 2006. Penelitian Tindakan Kelas. Jakarta: PT Bumi Aksara.

Badan Standar Nasional Pendidikan. 2007. Peraturan Menteri Pendidikan Nasional Republik Indonesia Nomor 41 Tahun 2007. Jakarta: BSNP.

Charuer, Kathy, dkk. 2005. Permainan Berbasis Sentra Pembelajaran. Beltsuillee, MD 20705: Translation Copyright 2005 by Penerbit Erlangga.

Dahar, Ratna Wilis. 1989. Teori-Teori Belajar. Jakarta: Penerbit Erlangga.

Daryanto. 1999. Evaluasi Pendidikan. Rineka Cipta: Jakarta.

Depdiknas, 2003c. Sistem Penilaian Kelas SD, SMP, SMA dan SMK. Dirjen Dikdasmen Tendik.

Depdiknas. 2002. Direct Instruction. Jakarta: Dirjen Pendidikan Dasar dan Menengah. 
Depdiknas. 2008. Pengolahan dan Analisis Data Penelitian. Jakarta: Direktorat Tenaga Kependidikan Dirjen PMPTK.

Depdiknas. 2011. Membimbing Guru dalam Penelitian Tindakan Kelas. Jakarta: Pusat Pengembangan Tenaga Kependidikan Badan Pengembangan Sumber Daya Manusia Pendidikan dan Menjaminan Mutu Pendidikan.

Dimyati dan Mudjiono. 2001. Belajar dan Pembelajaran. Jakarta: Dirjen Dikti.

Djamarah, Syaful Bahri. 2002. Prestasi belajar dan Kompetensi Guru. Surabaya: Usaha Nasional.

Hartinah DS, Haji Sitti. 2009. Konsep Dasar Bimbingan Kelompok. Bandung: PT. Refika Aditama.

Murjani, Ni made Sri. 2019. Penerapan Model Pembelajaran Direct Instruction dengan Media Gambar untuk Meningkatkan Prestasi Belajar IPS. Jurnal Penelitian dan Pengembangan Pendidikan. Vol.3 (3) pp. 264-270.

Pritandhari, Meyta. 2017. Implementasi Model Pembelajaran Direct Instruction Untuk Meningkatkan Kemampuan Berpikir Kreatif Mahasiswa. Jurnal Pendidikan Ekonomi UM Metro Volume 5 Nomor 1. 